\title{
Intersections
}

Canadian Journal of Music

Revue canadienne de musique

\section{Linda and Michael Hutcheon. 2015. Four Last Songs: Aging and Creativity in Verdi, Strauss, Messiaen, and Britten. Chicago and London: University of Chicago Press. 151 pp. ISBN 978-0-226-25559-0 (cloth), ISBN 978-0-226-25562-0 (ebook)}

\section{Colette Simonot-Maiello}

Volume 36, numéro 1, 2016

URI : https://id.erudit.org/iderudit/1043871ar

DOI : https://doi.org/10.7202/1043871ar

Aller au sommaire du numéro

Éditeur(s)

Canadian University Music Society / Société de musique des universités canadiennes

ISSN

1911-0146 (imprimé)

1918-512X (numérique)

Découvrir la revue

Citer ce compte rendu

Simonot-Maiello, C. (2016). Compte rendu de [Linda and Michael Hutcheon. 2015. Four Last Songs: Aging and Creativity in Verdi, Strauss, Messiaen, and Britten. Chicago and London: University of Chicago Press. 151 pp. ISBN 978-0-226-25559-0 (cloth), ISBN 978-0-226-25562-0 (ebook)]. Intersections, 36(1), 95-98. https://doi.org/10.7202/1043871ar

Copyright @ Canadian University Music Society / Société de musique des universités canadiennes, 2018
Ce document est protégé par la loi sur le droit d'auteur. L'utilisation des services d'Érudit (y compris la reproduction) est assujettie à sa politique d'utilisation que vous pouvez consulter en ligne.

https://apropos.erudit.org/fr/usagers/politique-dutilisation/ 
Linda and Michael Hutcheon. 2015. Four Last Songs: Aging and Creativity in Verdi, Strauss, Messiaen, and Britten. Chicago and London: University of Chicago Press. 151 pp. ISBN 978-0-226-25559-o (cloth), ISBN 978-0-226-25562-O (ebook).

Linda and Michael Hutcheon, prominent Canadian scholars of literary theory and medicine, respectively, are well-known to the academic music community. Four Last Songs: Aging and Creativity in Verdi, Strauss, Messiaen, and Britten follows the Hutcheons' three earlier music-related books, which broadened the scope of musicological inquiry by examining opera in an interdisciplinary context, intersecting music with medicine. Opera: Desire, Disease, Death (1996) examines themes of gender, sexuality, and disease in opera, while the Hutcheons' second book, Bodily Charm: Living Opera (2000) focuses on the operatic body. Opera: The Art of Dying (2004), part of Edward Said's Convergences series, addresses the theme of death in opera and opera's role in assisting its audience in coming to terms with mortality. The Hutcheons' most recent volume might be considered an outgrowth of Opera: The Art of Dying. Said himself inspired the authors with his scholarship on late style and prodded them to look more closely at Western concepts of gerontology, old age, and creativity. The Hutcheons responded with Four Last Songs, a title referring not only to Richard Strauss's famous late work, but also to four composers featured in this book's case studies who responded to the challenges of aging by composing opera.

In their introduction ("Setting the Stage"), the Hutcheons reveal that this book emerged, at least in part, from their contemplation of retirement following distinguished careers in academia and medicine, coupled with the knowledge that twenty-first-century expectations of retirement are vastly different than they were decades ago. The authors outline their methodology, provide a brief literature review on old age and creativity, and offer a rationale for their choice of composers in the introduction and the chapter following, titled "Creative Responses to the Challenges of Aging." The authors leaned heavily on sources that document the composers' own attitudes towards aging and creativity, such as interviews, correspondence, diaries, and autobiographies, and paid close attention to how the composers represented themselves. They focused on late works and their reception in their case studies, in particular emphasizing Verdi's Falstaff, Strauss's Capriccio, Messiaen's St. François d'Assise, and Britten's Death in Venice. The Hutcheons argue that opera composers are an ideal focus for a book on aging and creativity because opera can showcase the treatment of the human universal of aging, largely due to its reliance on both text and music. In addition, opera is a genre that exposes the 
composer's commitment of time and creative energy. The late nineteenth and early twentieth centuries are most appropriate for this study because opera composers of that era had more control over their subject matter and style than did earlier composers. Furthermore, gerontology and geriatrics emerged from the late nineteenth century, when old age was redefined as a social, economic, and medical construct. Finally, the Hutcheons outline two opposing models of creativity that were popular in the nineteenth century and demonstrate how they have been applied to composers' lives by critics and biographers. The biologically inspired model proposed that decline and degeneration followed a peak of maturity, while the aesthetic and metaphysical model suggested that artists rose to apotheosis and transcendence in their final years.

Several issues and themes emerge as points of comparison in the case studies. First and foremost, the Hutcheons assert that the meaning of age is culturally determined and attitudes towards aging and the aged are temporally and geographically specific. Second, a number of dichotomies are associated with the aging population. While they may enjoy a sense of contentment, they likely have to deal with worry and fear and they are simultaneously seen as both a burden on society and a source of wisdom and wealth. Third, a specific set of concerns can be applied to aging artists. For example, late works are charged with increasingly higher expectations from both the audience and the artists themselves. Artists are also expected to respond to changing tastes around them with consistent innovation and progress; in Four Last Songs, the composers' response to the rise of modernism is a special concern. Fourth, the authors paid attention to how each of the composers, while negotiating the typical concerns of old age, also attempted to control their legacies. Finally, viewing composers through the lens of aging and creativity foregrounded common faulty assumptions about late works, late style, and the arc of a composer's biography (e.g., that late works are typically sombre and autumnal in tone).

While the Hutcheons focus on Verdi, Strauss, Messiaen, and Britten, several other composers make their way into the book, including Wagner, not surprisingly as a foil to Verdi, and Jacques Offenbach, whose life story provides an introductory anecdote to the Verdi case study. While Offenbach composed Les contes d'Hoffmann (1881) at the end of his life in an attempt to leave a legacy as a serious opera composer and not "just" the founder of opéra bouffe, Verdi already had a reputation as a serious opera composer when he composed his final work, the comedic Falstaff (1893). Verdi's goal with Falstaff was to point the next generation of Italian opera composers in a new direction, away from Wagnerian influence. The Hutcheons highlight Falstaff's importance to Verdi's legacy with a compelling comparison to Wagner's final work, Parsifal (1882), arguing that both operas are about aging and generational crisis. They point out that Verdi's last opera's "relative brevity, its short melodic lines, its seeming refusal to repeat melodies, and even its hectic pace can all be read as ironic comments upon the length of line, frequency of motivic repetition, stately slowness, and sheer length of Parsifal" (p. 32).

In his later years, Richard Strauss kept his musical aesthetic in line with Nazi ideology in order to avoid risking his livelihood and putting his Jewish 
daughter-in-law and grandsons in danger. As a result, biographers often interpret Strauss's final decades as a slow decline away from a modernist aesthetic and his final opera, Capriccio (1942), as trivial, escapist, and even inappropriate in the wartime context in which it was written and premiered. The Hutcheons tell a different story, suggesting that when separated from its political context and examined instead in the context of Strauss's life, Capriccio acts as a summation work, or a musical "life review," meant as a self-evaluation to assess his legacy. Capriccio is an allegory that relates the history of opera, thus providing a review of the genre itself. By quoting prominent opera composers and placing quotes from his own music alongside these composers, Strauss strategically articulated his own legacy.

The Messiaen case study holds few surprises, in part because, as the Hutcheons point out, Messiaen's goals as a composer remained steadfast throughout his career. As a young composer, he unabashedly proclaimed that his music was a personal statement of faith meant to seduce the public towards spirituality. While he did attract an enthusiastic audience, he also became a target for France's secularized press, who argued that there was no place for his music in public concert culture and criticized the rambling theological commentaries that preceded performances of his works. In response, Messiaen turned to birdsong to represent the divine in nature, thus making the religious element of his music less overt. Decades later, Messiaen viewed a commission from the Paris Opéra as an opportunity to bring all of his musical and theological ideas together in St. François d'Assise (1983), an opera about a man who endured unimaginable physical and psychological pain to find perfect joy. In many ways, Messiaen's suffering in the eight years it took him to compose this work mirrored the experience of his protagonist. Not only was he afraid that he would die before he completed the work, but the opera stretched him to the limit physically, psychologically, and emotionally.

Of the four composers examined in this book, Britten stands out because he was still relatively young when he composed his final opera. Britten had postponed surgery to repair a failing heart valve while composing Death in Venice (1973) and, as a result, his health was declining rapidly. The Hutcheons contend that premature aging was devastating for Britten, who identified strongly with youth and vigour and who had become an active composer before reaching adulthood. His final opera acts as a summation work, reflecting Britten's personal experience in several ways. The protagonist faces a crisis of creativity, but the story is also about an older man's homoerotic desire for a much younger man, which serves to emphasize the protagonist's (and Britten's) premature aging. Like Britten, the character must abandon the youthfulness narrative that defines him. Britten suffered a stroke during surgery in 1973, when he was fifty-nine years old. He died in 1976.

In their conclusion, "The Particularities of Aging and Creativity," the Hutcheons point out that the range of experiences outlined in their four case studies, as well as in earlier research, including Michael Beckerman's work on Janáček and Simon Morrison's writings on Prokofiev, suggests that there are multiple narratives for old age and creativity. Four Last Songs is only one of a 
handful of books recently published on aging and creativity, or on late works more generally. Other recent publications include Bodley and Horton's Schubert's Late Music: History, Theory, Style and Elliott's The Late Voice: Time, Age and Experience in Popular Music. The Hutcheons' work is unique not only because they connect opera composition to aging, but also because they deliver an especially astute text with a strong medical angle, weaving historical and modern ideas of gerontology with cultural studies.

\section{REFERENCES}

Bodley, Lorraine Byrne and Julian Horton, eds. 2016. Schubert's Late Music: History, Theory, Style. Cambridge, UK: Cambridge University Press.

Elliott, Richard. 2015. The Late Voice: Time, Age and Experience in Popular Music. London, UK: Bloomsbury.

Hutcheon, Linda and Michael. 1996. Opera: Desire, Disease, Death. Lincoln, NE: University of Nebraska Press.

- 200o. Bodily Charm: Living Opera (Abraham Lincoln Lecture Series). Lincoln, NE: University of Nebraska Press.

-2004. Opera: The Art of Dying (Convergences: Inventories of the Present). Cambridge, MA: Harvard University Press.

Colette Simonot-Maiello

\section{BIOGRAPHY}

Colette Simonot-Maiello teaches musicology at Brandon University, where she is also Chair of Music Research. Her research focuses on issues of gender, religion, and genre in 2oth and 21st-century opera, especially the works of Francis Poulenc. She also writes about Canadian opera, folk, and popular music, and is currently investigating the figure of Louis Riel in musical culture. 